\title{
Orientalist Paintings and Said Orientalism
}

\author{
Zahra Sadat Ismailinejad* \\ Shiraz University, Iran \\ *E-mail address: zahra.ismaily@yahoo.com
}

\begin{abstract}
Westerners came to this conclusion that to dominate Orient, they should gain sufficient knowledge about them. Therefore, they established the so-called field of Orientalism to study Orient since this knowledge gave them the power to rule. Based on this type of knowledge, they thought that there were sharp contrasts and differences between Orient and Occident and they tended to gain advantage from them. The problem started when Orient internalized these notions and embraced them with open arms due to the inferiority complex that was imposed on him. Orientalist painters also took their cues from the Orientalism to reflect their governments' ideas and politics in disguise. These paintings began in nineteenth-century and different artists from Britain, France, Italy, Germany and Spain went to the East or started to paint based on others' paintings or description of Eastern land. The problem is that some of these painters were first-hand observers but some others let their imaginations to shape their conceptions of Orient. Here, attempts have been made to review these paintings based on Said's book, Orientalism.
\end{abstract}

Keywords: Textual Attitude; Orientalized Orient; Superiority V.S. Inferiority; Statics and Fixity of Orients; Utilitarianism; Power and Knowledge; Good Orient and Bad Orient; Said; Orientalism

\section{INTRODUCTION}

Edward Said is one of the grand old masters of post-colonial studies. The theoretical framework of this paper is based on Edward Said's theory of Orientalism that is offered in his book of the same title, Orientalism (1987). His Orientalism is endowed with big themes and is known to be as the crowning achievement of post-colonialism. The book brings to the central focus, the way in which prejudices and misapprehensions rule over western's thought and image of Orient to the extent that they utilize these false views to claim that Occident is superior while Orient is inferior in every facet and dimension.

To him Orientalism is a "style of thought based upon an ontological and epistemological distinction made between "the Orient" and (most of the time) "the Occident."'(Said, 1977, p.3) He also claims that Orientalism is a western strategy based on biases and prejudices which they make the most of them as their justifications for their material exploitations. Occident portrays Orient devoid of any culture, reason, to name just a few. It is mainly a discourse to rule over Oriental lands and to shape Orientalized Orient who can best serve Occidents. He brings a lot of evidences to show the existence of these misconceptions and misunderstandings to prove that Westerners are on the wrong track. One can see clearly that Orientalism is "a Western style for dominating, restructuring, and having authority over the Orient." (Said, 1977, p.4) 
Orient and Occident are arbitrary terms and the Oriental qualities and characteristics are designated to Orient by Occident. As Said defines Orient in this way "The Orient is not only adjacent to Europe; it is also the place of Europe's greatest and richest and oldest colonies, the source of its civilizations and languages, its cultural contestant, and one of its deepest and most recurring images of the Other" (Said, 1977,p.2). But for Americans the concept of Orient and its representation are a bit different since they associate it more with "the Far East (China and Japan mainly)" (Said, 1977, p.2). French and England used to be great masters of Orientalism. After the end of World War II, "America has dominated the Orient, and approaches it as France and British once did." (Said, 1977, p.5) Throughout history, even before the age of colonial expansion, Westerners considered this as an undeniable fact that Orients were barbaric and uncivilized race, they remained the same and no change or development would occur to them. They take a step further and define themselves in terms of Orient "The Orient has helped to define Europe (or the West) as its contrasting image, idea, personality, experience". (Said, 1977, p.2)

So the Orient as an inferior race associated with barbarism, passivity and Occident is whatever Orient fails to be. This sense of superiority enables them to usurp and exploit Oriental lands and present a false image of them. Just like America which dubbed itself as world super power and uses terrorism as an excuse for Iraq and Afghanistan War with these nations' inabilities to tackle this problem as its justification. The main problem is that they tend to generalize these artificial characteristics to all Orients and portraying them in their literary, artistic, and scientific works. These generalized attributes still linger in today's world, for example, they say all Muslims are not terrorists but all terrorists are Muslims.

Orientalists tend to describe and define the Orient and even the very existence of Oriental studies is a strategy to dominate and form the world's conception of Orient and their relationship is characterized by one-way power and domination. In fact, to Said, Orientalism is more a sign of "European- Atlantic power" than being a "discourse about the Orient" (Said, 1977, p.7). They do not limit themselves to the theoretical discussions and take a step further to reflect their doctrines and justification in their literature, art, and culture since they have their own definition of Orient. Orientalism, to them is" a school of interpretation whose material happens to be the Orient, its civilizations, peoples, and localities."(Said, 1977, p.204) One can see major issues that Said addresses them in Orientalism like Orients as inferior race, their fixity and unchanging nature and the civilizing mission of Westerners as their major excuse for their presence can be seen in these paintings. The views of Orientalist painters regarding Orient are closely akin to each other and at the same times are reflections of their governments' politics and ideologies regarding Orient as Cynthia Weber well claims "much politics is conducted through... visual language" (As cited in Khalid,2011,p.16). What Said argues for critically and philosophically, they depict it aesthetically. In fact, a review of their works further makes clear the big themes in Said's ground-breaking book. According to Said "The Orient was almost a European invention, and had been since antiquity a place of romance, exotic beings, haunting memories and landscapes, remarkable experiences.'(Said, 1977, p.1)

So the European tend to use it as their source of inspiration as if nature does not endowed them with enough materials for their artistic works. Objectivity seems inept to them, what is important for them is a Western representation of Orient. As Karl Marx puts it in this way "they cannot represent themselves; they must be represented" (As cited in Said, 1977, p.1). So they cover the real motivation for colonialism, they were there for the good benefit of Orient and now, they are in serious need of being represented by Westerners since Orients are incapable of representing themselves. What is interesting here is that none of these 
paintings are drawn by Orient themselves. The relationship between Orient and Occident is best depicted by these paintings which are rich sources for Orientalistic analysis.

\section{DISCUSSION}

\subsection{Textual Attitude}

Textual Attitude entails an unknown, doubtable situation in which books or texts can provide the readers with clue or knowledge about the real lives of human beings but there is a constant danger of falling into superficial conclusions or misapprehension that are the result of biases incorporated within the texts. It occurs in two situations. The first case occurs when a person confronts a situation that is far unusual for him so he has no experience about this situation but he may read about it previously. In this situation, the book acquires a greater authority, and use, even than the actuality it describes."(Said, 1977, p. 94) This is the case with this anonymous painting which depicts the gate of Damascus but this dear with anther is never existed in Syria up to this time.

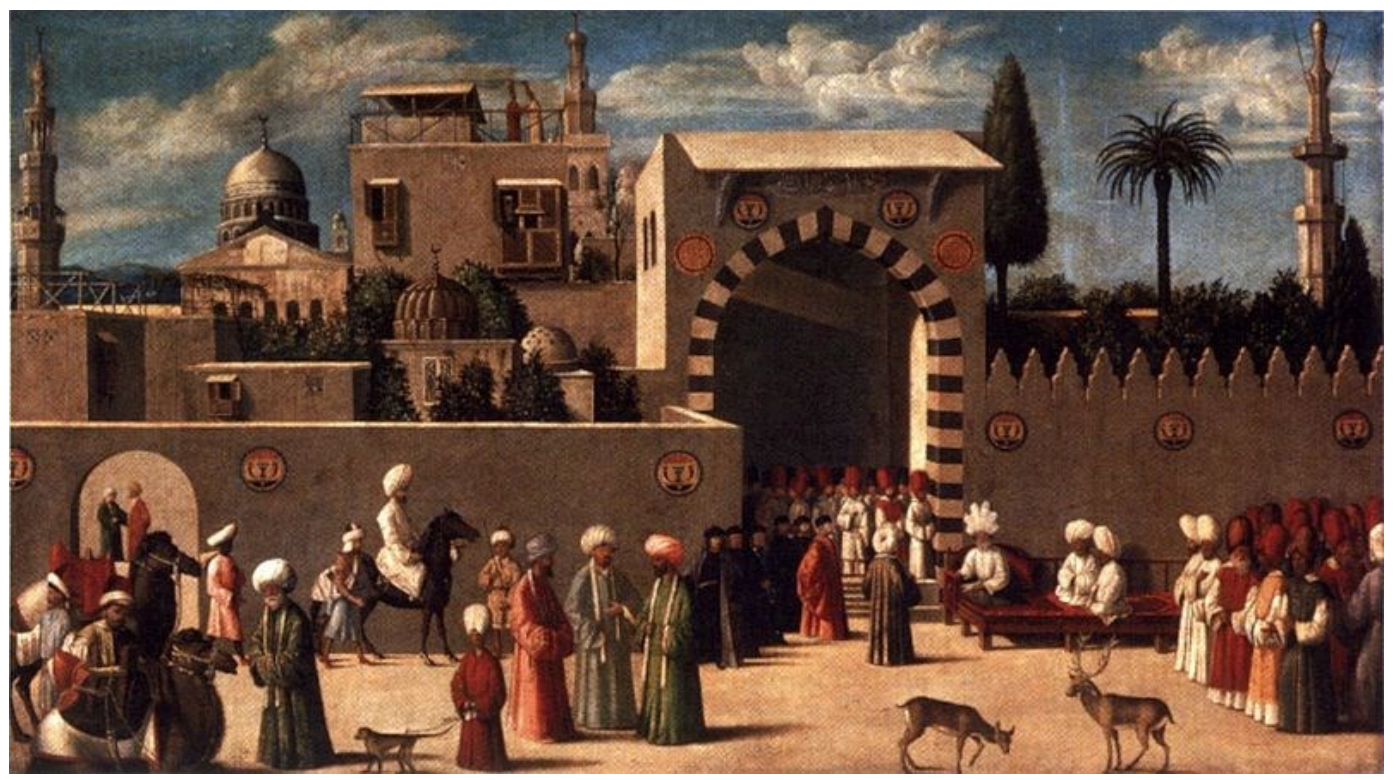

Figure 1. The Reception of Ambassadors in Damascus, 1511.

All the famous painters who tried their hand on depicting the Harem are proved to be wrong in what they depict since none of them had permission to enter inside the house. So they used their imaginations and fantasies about Eastern Harem based on what they read about East. Here, Arabian Nights is somehow responsible for this misconception since it presents the East as the land of lust and lechery peopled with superstitious folk who are obsessed with sex and violence as if they are brutal murderers with no sense of humanity and pity. The following painting "Women and an Old Man in Harem" by Walter Charles Horsley is a good example. The painter resorts to his imagination and the painting shows his little knowledge. May be he is a second-hand observer who inspires by other works. He may be true in his depiction of scenery and architectural quality of Eastern house at that time but the interesting point is that he draws on the women in his society and the blonde woman inside 
the Harem is not of Oriental complexion. But when Henriette Brown's "Visit, Harem Interior" presented a real picture of Harem interior since she was a woman and could enter the Harem based on Islamic law. As we see, there is a sharp contrast between the two paintings. What Walter Charles Horsley depicts is a sort of "constructed representation" which is Western strategy to represent Orient as a closer way to what they have in mind. So both the Occident and Orient internalized this ideology of Orientalism as Other "different, inferior" and Occident "superior" (Bailey\&Gayle, 2005, p.42).Reina Lewis (2003) discusses this problem why Ottoman women in the nineteenth-century could not fight these Clichés about Harem. First, there were few literate women among elite families and second, those who wanted to take action were not literate in European languages. (96)

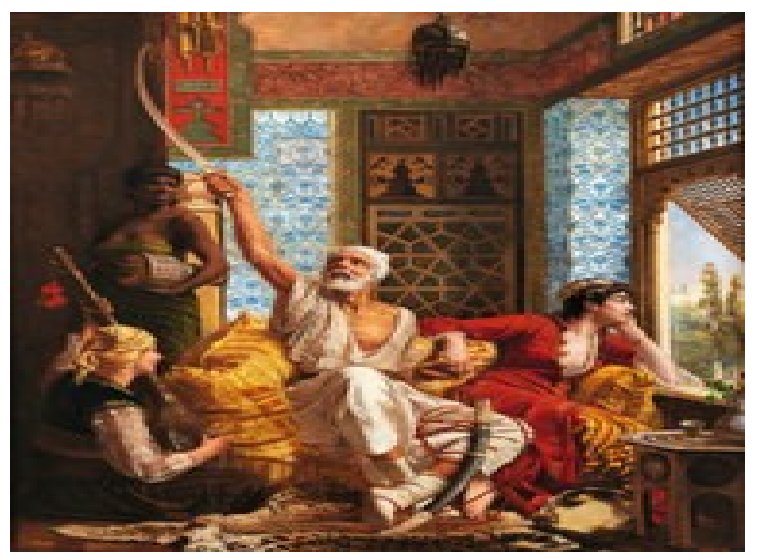

Figure 2. Women and an Old Man in Harem by Walter Charles Horsley, 1883.

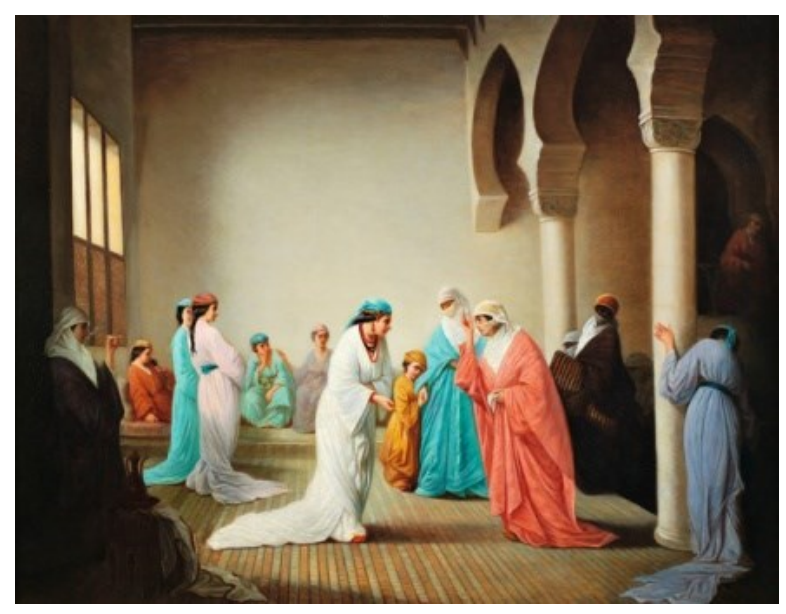

Figure 3. Visit, Harem Interior by Henriette Brown, 1860.

The second situation occurs when success comes in between. When the reader sees what the book says is in accordance to reality, he kind of believing in that author and this in turn, helps other books to be written related to subject of successful book. So, Occident gains some sort of knowledge by reading books on Oriental as was the practice of some painters who paint based on what they read or saw in the works of other painters. As Said states "What Orientalists like Lane, Sacy, Renan, Volney, Jones, and other pioneers made available, the 
literary crowd exploited."( Said, 1977,p.169) Then after they win the confidence of their readers, they turn to other subjects and little by little their success can help the development of the field to the extent that their painting have past their classic era and enter into modern and postmodern era like Jacques Majorelle who turns to abstraction in his painting" L' Aouche".

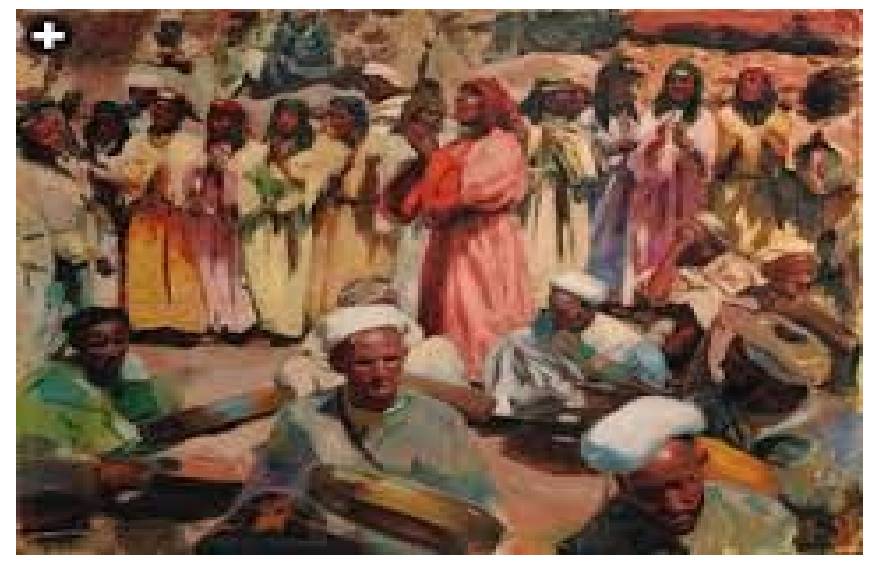

Figure 4. Jacques Majorelle's L' Aouche.

\subsection{Orientalized Orient}

Said believes that some Orientalists texts contain some truth in their relation to the reality of the Orient, but that is not of his concern in Orientalism. What in this paper is going to be discussed is the very process of Orientalized Orient. By this process, the Orient suffers a sort of alienation and comes to this view that they are inferior race, back warded, incapable of governing themselves so they are in urgent need of West's help. These paintings reflect the Westerners conception of Orient since they see them as different race .They just show what passes their mind regarding the Orient but at least they are honest and state their ideas unconsciously yet outspokenly if we compared the western painters to their politicians. They make them to believe that "Orient born out of Orientalist efforts" (Said, 1977, p.88). Little by little, the Orient internalizes these ideas and accepts the superiority of Westerners and their life style. So that they shape Orient ideology and worldview to the extent that "make the Orient speaks, describes the Orient, renders its mysterious plain for the West"(Said, 1977, pp.21-22). It is what Edward Said means "Orienalized Orient" i.e. accepting to be object of Occident.

He claims that "The Orient was Orientalized not only because it was discovered to be "Oriental" in all those ways considered commonplace by an average nineteenth-century European, but also because it could be - that is, submitted to being - made Oriental. "(Said, 1977, pp.6-7) The effect of Orientalistic paintings on the mind of Orient is that they are the number one customers who buy these painting and each year spending thousands of thousands dollars on buying these works. These paintings are dear to them since they think that these paintings are parts of their national heritage. Here, Orients internalized these notions of Westerners about them as if they can see their live history in them. Mohammad Racim as an Algerian artist shows a group of Persian hunters who violently attacked innocent gazelles with arrows which were quite out of style as a weapon in the minds of Westerners even at that time. The presence of nomad in the picture further worsens the problem as they thought of Easterners as uncivilized and barbaric. And Benjamin (2003) also believes that his 
works is somehow "a Maghrebian self-affirmation in the face of the colonial presence." (p.222)

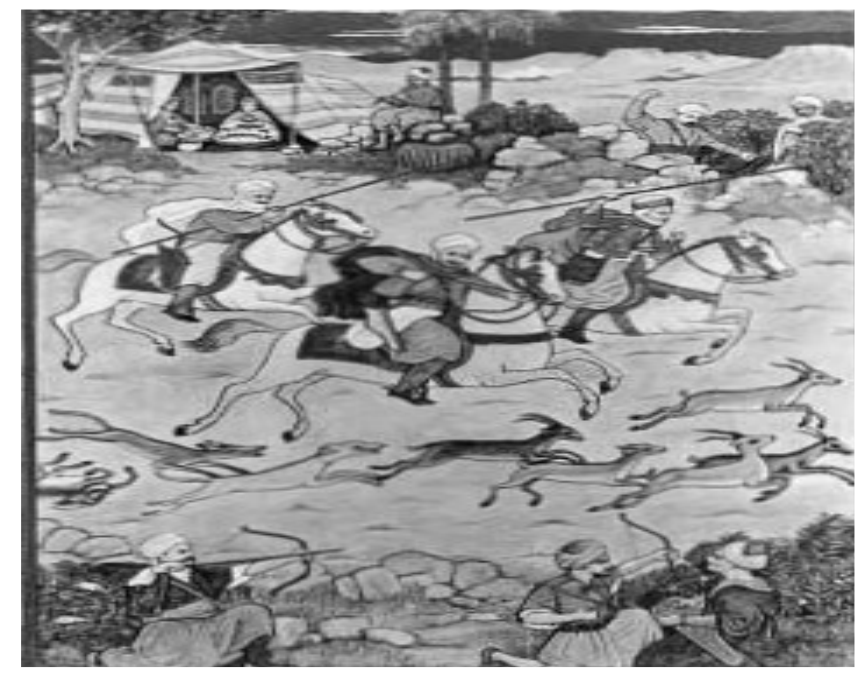

Figure 5. Persian Hunt by Mohammed Racim 1920.

\subsection{Superiority V.S. Inferiority}

Said asserts that the Orientalists do not innocently describe the Orient but also create and maintain the Orient. Occident considers himself superior to the Orient and Said thinks that the root of this feeling is in the color of the skin. The color of the skin give them the legitimation to govern non- white ones; they even draw to Charles Darwin's Theory of Evolution that believes in gradual development of animals and plants to give legitimization to this notion" Being a white man was therefore an idea and a reality. It involved a reason position towards both the white and non-white worlds." (Said, 1977, p. 227) So, their whiteness provides them a privilege to take hold of "reality, language, and thought." (Said, 1977, p.227)They choose Orient as their subject of study to discover and analyze such strange creature since he is "a living tableau of queerness." (Said, 1977, p.104) They claim that this definition of Orient is a service to them since it "lifts them from the realms of silent obscurity into the clarity of modern European science" (Said, 1977, p.87). They embark on a mission of describing Orient in their own terms and reach to the conclusion that Orient is "gullible, "devoid of energy and initiative," much given to "fulsome flattery," intrigue, cunning, and unkindness to animals" (Said, 1977, p.39). They draw on the dichotomy of Self and Other and define Orient and at the same time they are the opposite of what Orient is "The Oriental is irrational, depraved (fallen), childlike, "different"; thus the European is rational, virtuous, mature, "normal."'(Said, 1977, p.41) Figure 6 shows the spirit of colonialism at best. The statue of the colonizer shows the superiority of conquers over natives since they are incapable of governing themselves since they are uncivilized and inhuman. They are always depicted as brutal who just want to wage war as they depicted in figure 7 . 


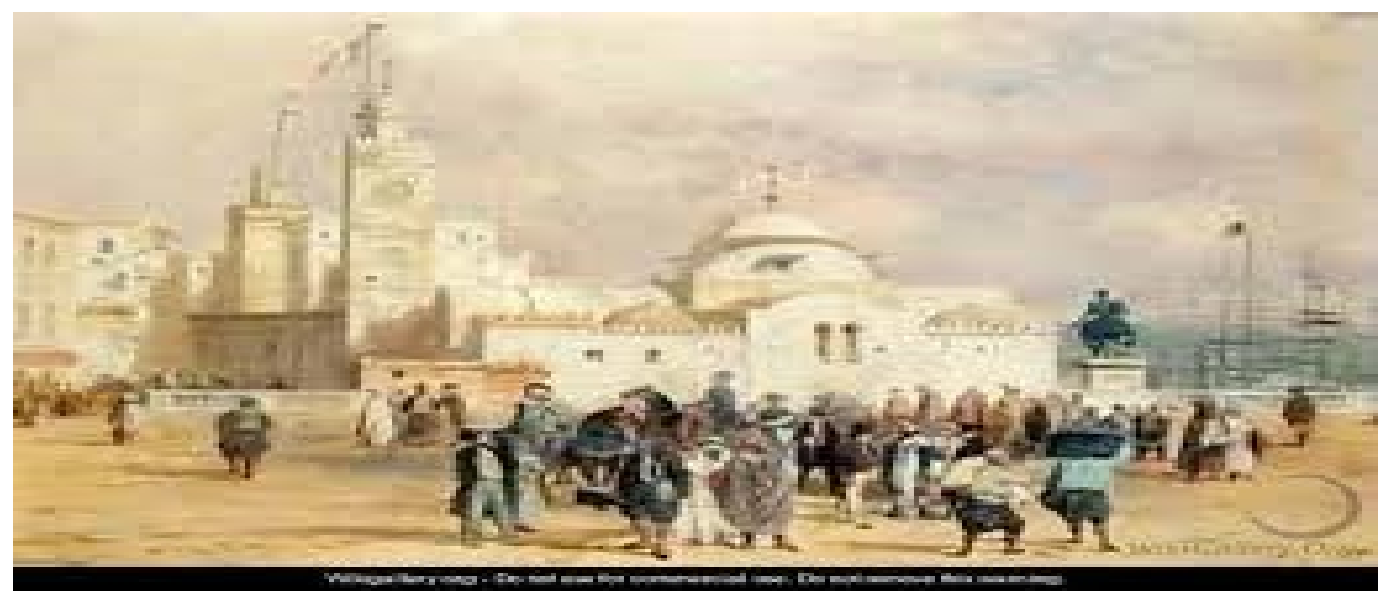

Figure 6. Adrien Dauzats, The Place du Gouvernement at Algiers, 1849.

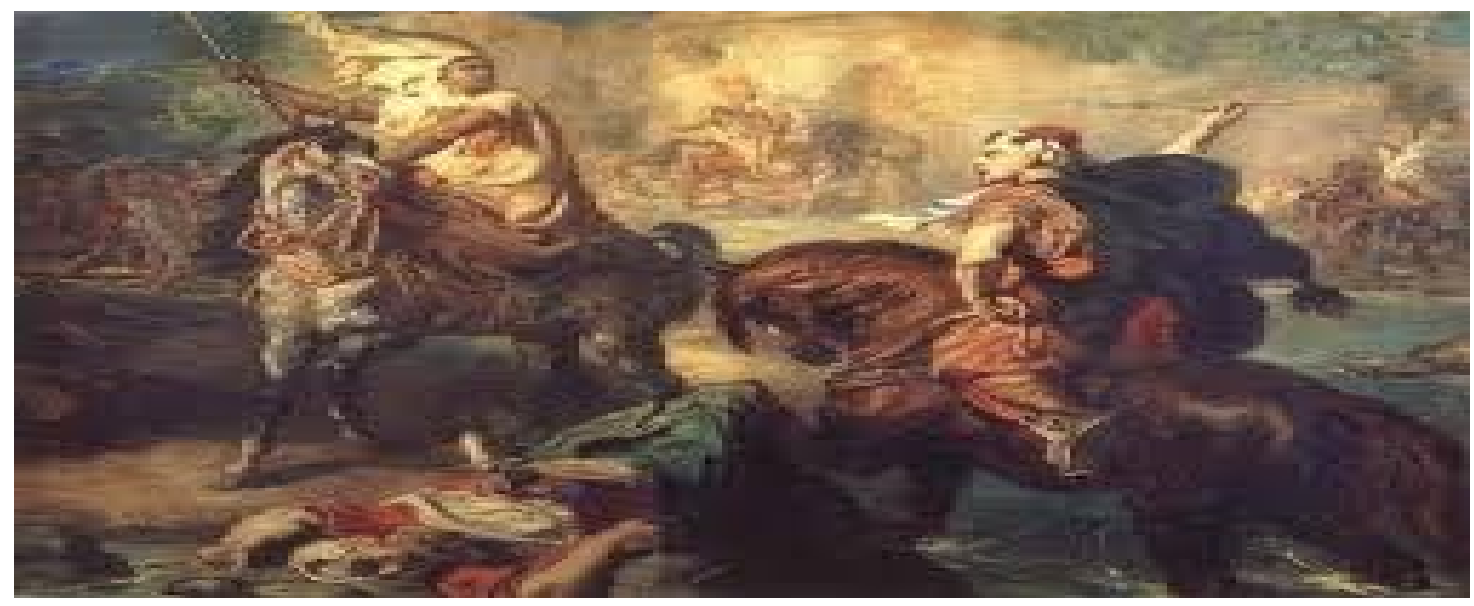

Figure 7. Théodore Chassériau, Arab Chiefs Challenging Each Other to Single Combat under the Ramparts of a City, 1852.

While British Army during the nineteenth century used to retire its officers when they reach the age of fifty because "no Oriental was ever allowed to see a Westerner as he aged and degenerated" (Said, 1977,p.12) but they tended to present only old, poor Orient to confirm their superiority in a win-lose battle. 


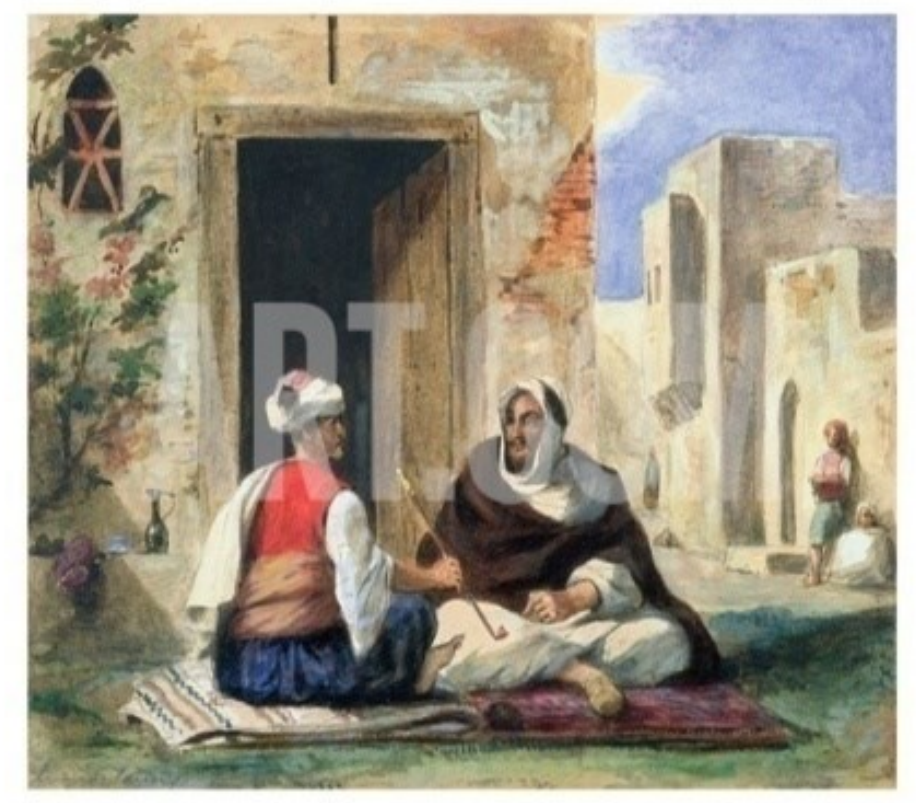

Figure 8. Eugene Delacroix, Arab Men Smoking in front of a House.

\subsection{Statics and Fixity of Orients}

Orientalism tends to compare the familiar Western world with the exotic, mysterious East. It seems that Orientalism gives the Westerner some sort of proof that Oriental culture and ideologies are far more inferior to the West so they regard them as uncivilized and accord them a lower position. But the problem is that "Orientalism had no corresponding equivalent in the Orient" which can be best termed as a "one way exchange." (As cited in TavakoliTarghi, 2001, p. 19) This study of Orient comes to shed light on the being of Orient since it turns out to be an object of study which provides them with information about it. They came to this conclusion that "the Orient is essentially monolithic, with an unchanging history, while the Occident is dynamic with an active history" (Said, 1977, p. 64) or" the Orient and Orientals are seen to be passive, non-participatory subjects of the study" (Ashcroft and Ahulwalia, 1999, p. 64). One of the main issues in western Orientalism is the fixity of Orient. Said states that most the Orientalists believe that the Orient never changes and it "has remained fixed in time and place for the West."(Said, 1977, p. 109) On the other hand, The West is "the actor; the Orient is the passive reactor. The West is the spectator, the judge and jury, of every facet of Oriental behavior." (Said, 1977, p. 110). These painters always try to show the unchanging nature of Orient life as if there is no hope of a better, developed life for these folks. While Westerners enjoy luxurious lives these Oriental women live in places that Westerner cannot picture them and even their animals live in more decent places. They present a romantic picture of Orient as non-changing race but "there is disappointment that the modern Orient is not at all like the texts." (Said, 1977, p. 101)As Gerade de Nerval laments in a letter to Theophile Gautier that everything changes and his dreams are betrayed and now he needs to resort to images in his imagination. 


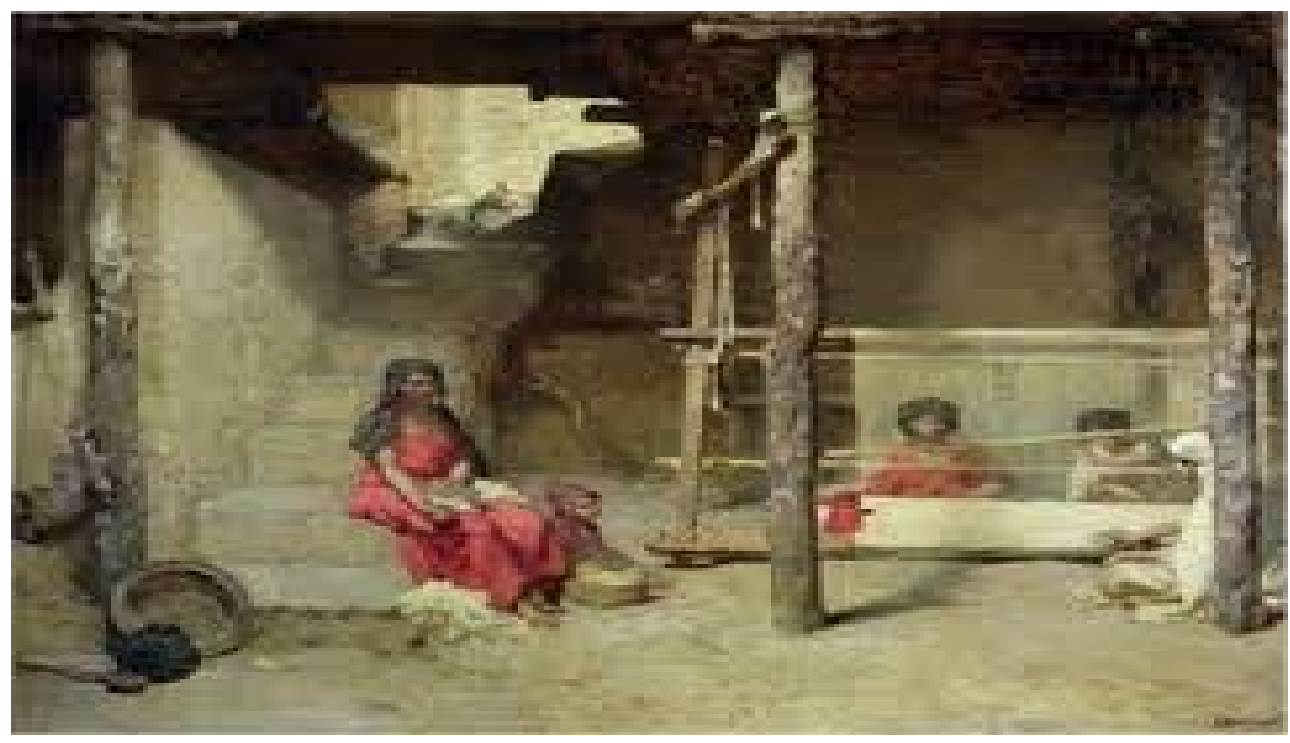

Figure 9. Gustave Guillaumet, Weaving Women at Bou-Saâda, 1885.

Therefore, Western Orientalists claim that Orient has no history, because it is stable and fixed without any change, and that Orientals are primitive and simple because they do not have any wisdom. Said uses this discourse and argues that Western cultural institutions are responsible for the creation of those 'Others'. It is their strategy to establish this binary opposition of Occident and Orient or Self and the Other to claim "the naturalness and primacy of the colonizing culture and world view "(Ashcroft et al., 2000, p. 155). Then he adds that is always depicted in need, he even has no knowledge of himself and is faced with this fact that there is always "a source of information (the Oriental) and a source of knowledge (the Orientalists)" (Said, 1977, p. 309). In an article in the book Orientalism Revisited: Art, Land, and Voyage, Zahia Smail Salhi (2012) comments about Alloula's book The Oriental Harem which is a collection of photos taken by Western photographers. Her comment can be applicable to the analysis of these paintings as she says "They turn the difference into hierarchy; it highlights the difference between "self" and "Other" in terms of hegemonic power relations.'(p.258)

\subsection{Knowledge and Power}

Orientalism is best viewed in Foucauldian terms as a discourse to manifest power and knowledge. Said's argument about knowledge and power in the relationship of Orient and Occident is best demonstrated by Prime Minister Arthur Balfour's defense of Britain's occupation of Egypt in 1910, justifies Britain's occupation of Egypt because they had knowledge and not because of their military or economic power. This knowledge give them the power to dominate Egypt to the extent that he believes that the best government for Egypt is their ruling over it "To have such knowledge of a thing [as Egypt] is to dominate it, to have authority over it.... Since we know it and it exists in a sense, as we know it" (Said, 1977, p. 32). Orientalism is there to gain a better knowledge of Orient to rule them which emphasizes the powerfulness of West in the face of weak East, therefore, highlighting its inability and weakness since "knowledge gives power, more power requires more knowledge, and so on in an increasingly profitable dialectic of information and control"( Said, 1977, p. 37). Since he has knowledge, he thinks that he is superior and feels some sort of power over Orient. 
Occident possesses the knowledge and Orient is in urgent need of it. His knowledge justifies what evil he does. What we see in this painting that they have no knowledge in fact as they claim. Ingres as a male was not allowed to thread in a bath full of women, he just depicted his sexual fantasies because all these women have fair skins and European complexions. This is imperfect kind of knowledge they claim as their source of power. They are so confident in depiction of Orient as if they know them better than the Orient themselves.

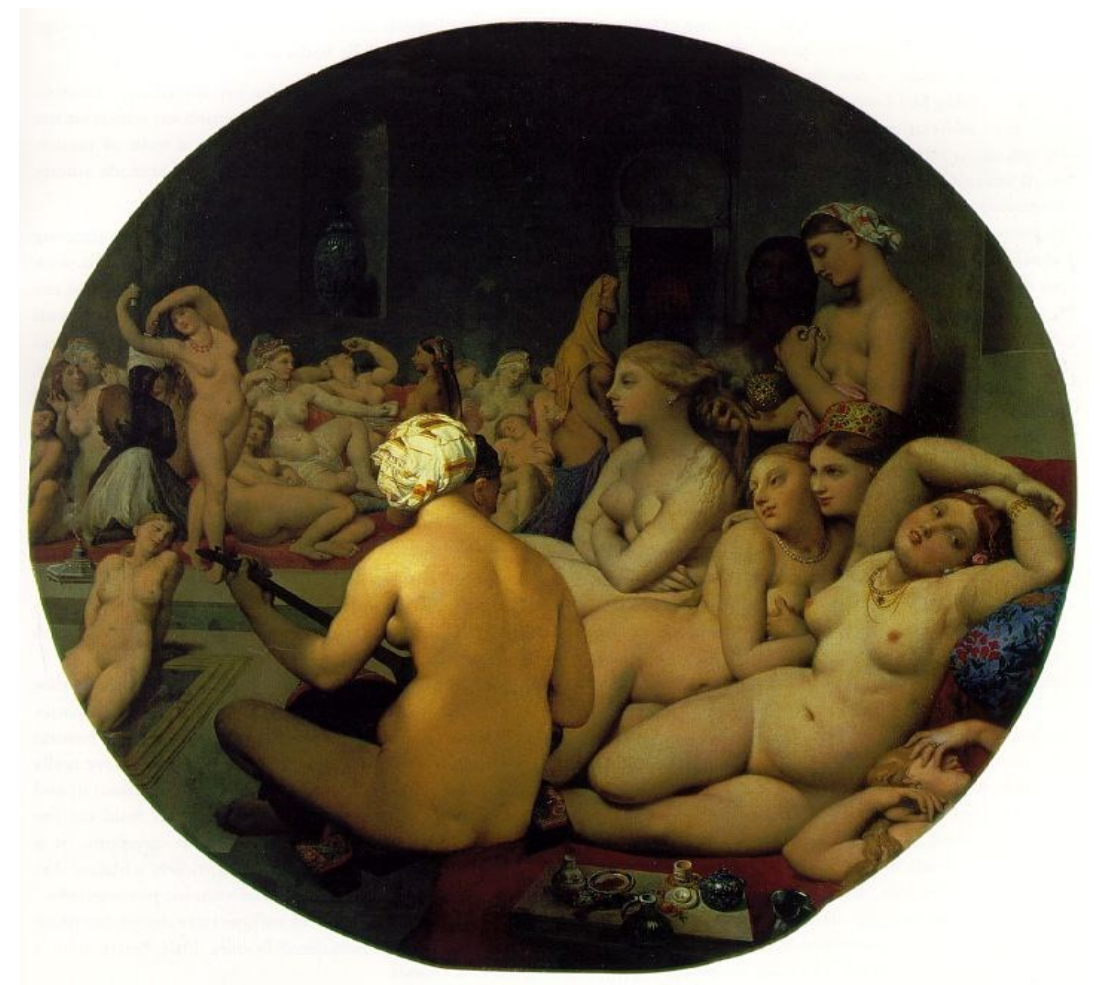

Figure 10. Turkish Bath by Jean Auguste Dominique Ingres, 1862.

\subsection{Good Orient and Bad Orient}

Said asserts that the westerners draw a line between good Orient and bad Orient. As he suggest" Orient was invariably a classical period somewhere in a long-gone India, whereas the "bad" Orient lingered in present-day Asia, parts of North Africa, and Islam everywhere" (Said, 1977, p. 100). What the Westerners mean by good and bad Orient actually is nothing but awareness of the latter of the fact that they are not to be only observers of what is going on around them but they rather have the right to ask for their rights. 


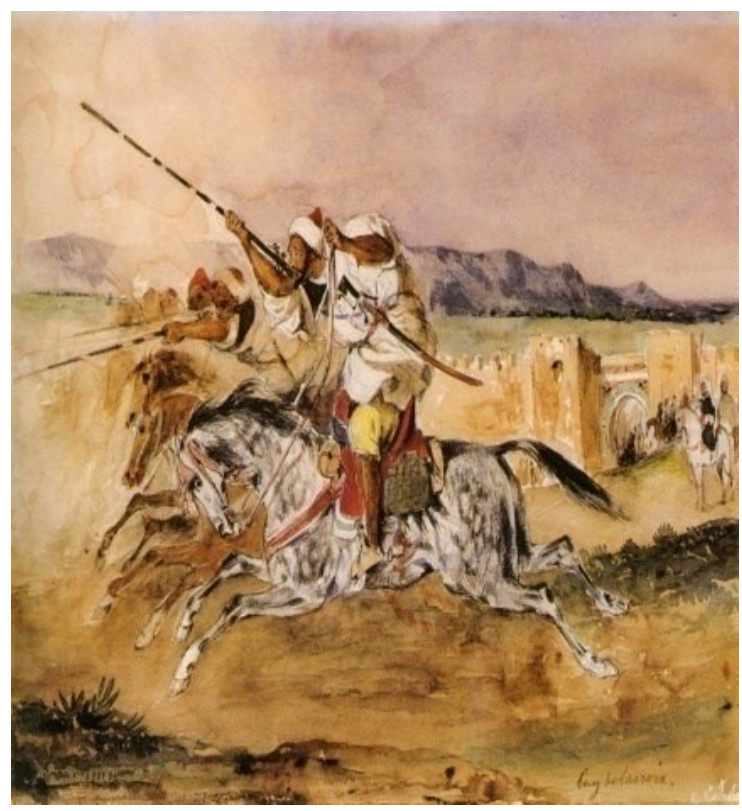

Figure 11. Arab Fantasia by Eugene Delacroix.

To them, Good Orient is the one who internalized this notion of Occident superiority and does to get them into trouble anymore and his or her character is in agreement with their clichés. But an Orient should bear in mind that "he is first an Oriental, second a human being, and last again an Oriental" (Said, 1977, p. 103). Flaubert presented a cliché of Oriental woman:

She never spoke of herself; she never represented her emotions, presence, or history. He spoke for and represented her. He was foreign, comparatively wealthy, male, and these were historical facts of domination that allowed him not only to possess Kuchuk Hanem physically but to speak for her and tell his readers in what way she was "typically Oriental". (As cited in Said, 1977, p. 7)

\subsection{Utilitarianism}

The Orients were regarded as uncivilized, unchanging people, incapable of running their affairs and on the other hand we have Westerners who are of a superior race so it is their duty to civilize these people and in order to achieve their goals, they had to colonize and rule the Orients. They said that the Orients themselves were incapable of running their own government. Europeans also thought that they had to colonize and rule the Orients. In fact, it is "their "civilizing mission" to bring order and civilization to the barbarous hordes" (Ashcroft, 2001, p. 1).

Everything associates with Occident is good and superior and everything associates with the Orient is evil and inferior so, the Occident starts a mission of civilizing and humanizing the Orient. Occident always consider Orient as creature but here, the benefit and pleasure is in between and she is the most pleasing of all. As Balfour said once "We are in Egypt not merely for the sake of the Egyptians, though we are there for their sake; we are there also for the sake of Europe at large." (As cited in Said, 1977, p. 33) Here he kind of confesses that although they have this so-called civilization in mind that also have an eye on 
their own benefit. As Gabriel Charmes claims if the era of colonial expansion comes to an end "One of the most fruitful sources of our national wealth will be dried up."(As cited in Said, 1977, p. 220) This honest painting shows that not only they can use their art to propagate their governments' messages but also they gain so much money with this business of Orientalist painting. As this is the common practice among some Iranian directors to show the kind of materials that Westerners want to see of Orient to win awards in various film festivals like Majid Majidi, Abbas Kiarostami. The only director who manages to show a real picture of Iranian society without resorting to some poor family problems is the Oscar-winning Asghar Farhadi whose Nader and Simin: A Separation could succeed with its universal themes that are common among different societies at different eras.

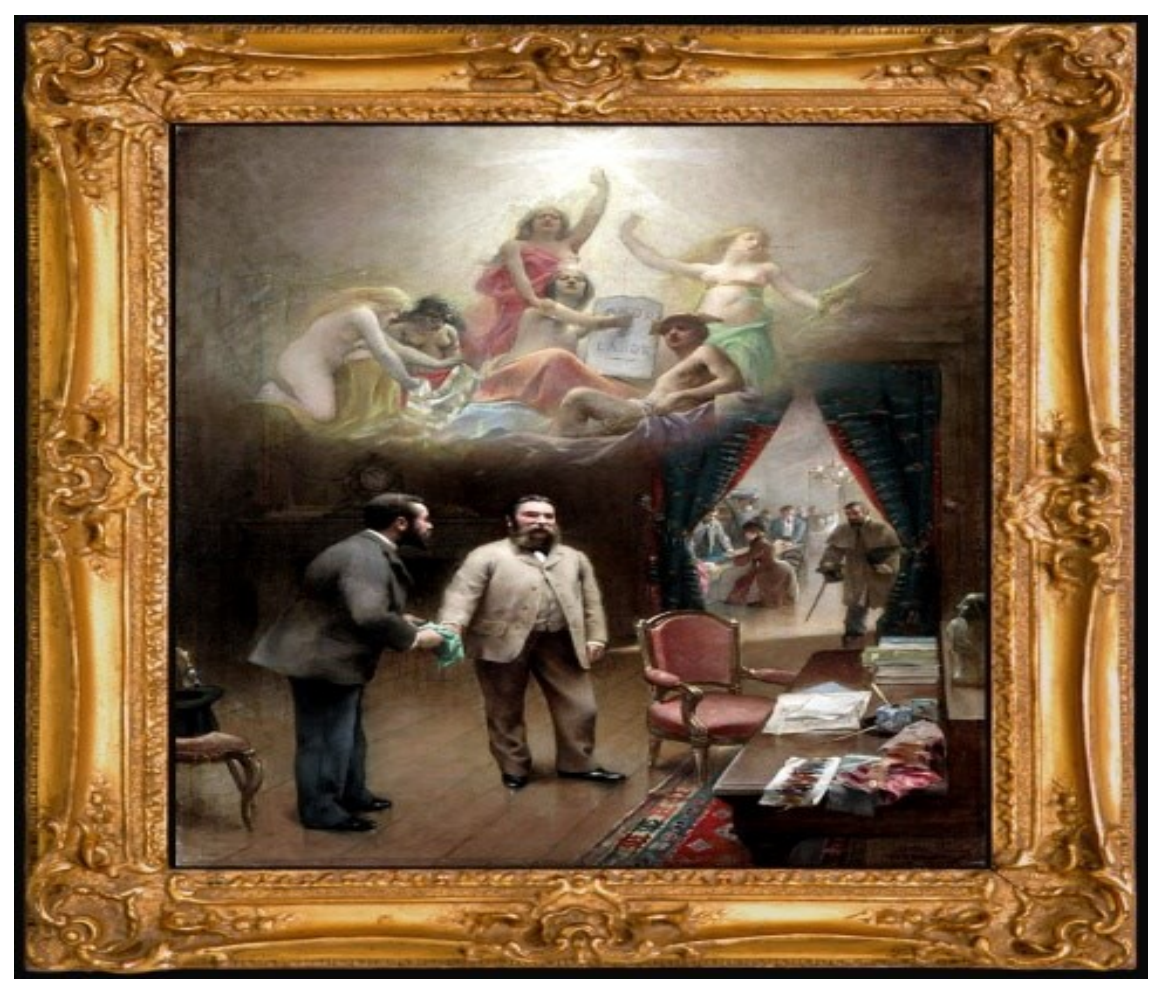

Figure 12. "The Next Commission” by H. Adrien Tanoux, 1889.

\section{CONCLUSION}

Although the era of colonialism is long past but the truth is that after the awakening of some colonized nations and their attempts and success to regain their lands from the colonizers, this struggle between the colonizers and colonized still remains. The fact is that, the ways of colonization and decolonization are changed. Therefore, Orientalistic discourses and studies are continual processes, and are improving day and night from a prejudiced perspective of inferiority and backwardness of Orient, it is necessary to get along with it, understand and analyze it well in order to repel the Orientalizing influences of it. In short, Orientalism is nothing but a matter of Occident's hegemony, authority or supremacy over the Orient that forms a hegemonic relationship in which Orient has to be a follower and subordinator of the Occident. What Said adheres is the eradication of this hegemonic relationship to help East and West get closer to each other. Just as Said's book criticizes 
Orientalists and their subjective accounts of the East and at the same time challenges their works, there is a similar movement to respond to some of these Orientalist painting by Oriental painters. As we see it in her response to Delacroix's painting of Algerian women and her response work entitled not to torture which shows these women as normal human being, focusing more on human nature than a surface representation to show that they went through many miseries and hardships during colonial era.

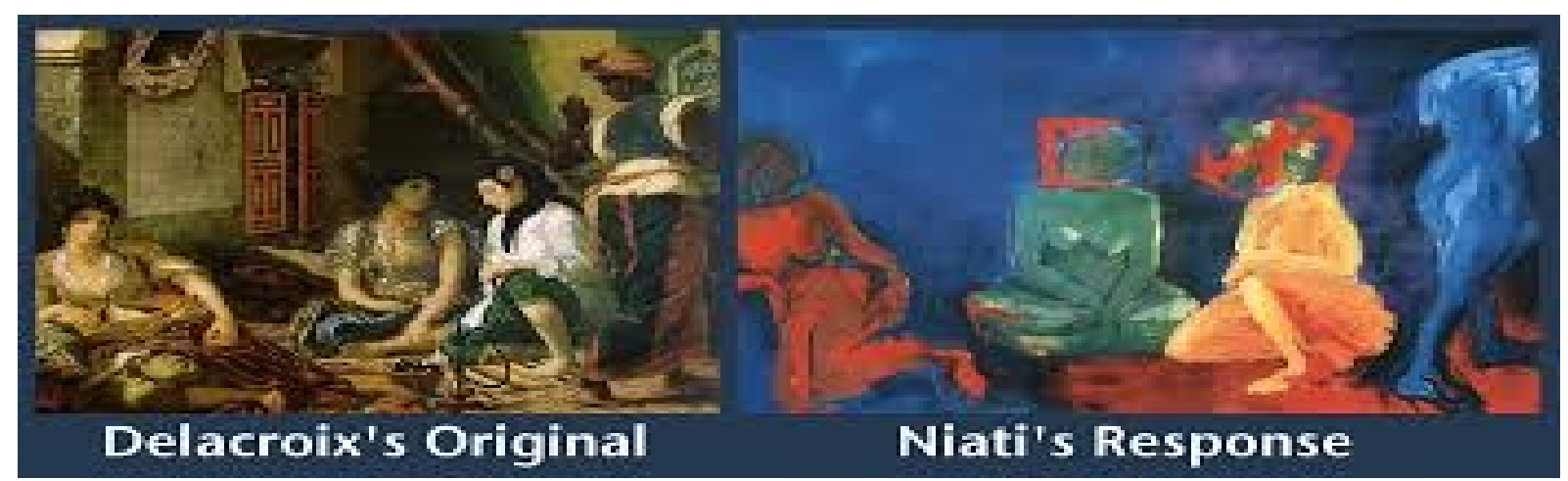

Figure 13. Algerian Women in Their

Figure 14. No To Torture, Houria Niati, 1982. Apartments by Eugene Delacroix, 1834.

\section{References}

[1] Ashcroft, B., \& D. P. S. Ahulwalia. (1999). Edward Said. New York: Psychology Press.

[2] Griffiths, G., \& Tiffin, H. (2000). Post-colonial Studies: The Key Concepts. London\& New York: Routledge.

[3] Post-Colonial Transformation. (2001). London\& New York: Routledge.

[4] Bailey, G., \& Gayle N. (2003). Ideology: Structuring Identities in Contemporary Life. Toronto: University of Toronto Press.

[5] Benjamin, R. (2003). Orientalist Aesthetic: Art, Colonialism, and French North Africa, 1880- 1930. Berkeley/ Los Angeles/ London :University of California Press.

[6] Khalid, M.(2011). Gender, Orientalism and Representations of the 'Other'in the War on Terror. Global Change, Peace \& Security: formerly Pacifica Review: Peace, Security\& Global Change, 23 (1), 15-29. Retrieved from http://dx.doi.org/10.1080/14781158.2011.540092

[7] Lewis, R. (2005) Oriental Femininity as Cultural Commodity: Authorship, Authority, and Authenticity. In J. Hackforth-Jones \& M. Roberts. (Eds.)Edges of Empire: Orientalism and Visual Culture. Malden: Blackwell Publishing.

[8] Said, E. (1977). Orientalism. London: Penguine.

[9] Salhi, Z. S. (2012) Maghreb and the Occident: Towards the Construction of an Occidentalist Discourse. In I. Richard Netton (Ed.). Orientalism revisited: Art, Land, and Voyage London\& New York: Routledge.

[10] Orientalist Paintings. (n.d.). In Wikipedia. Retrieved August 14, 2014, from http://en.wikipedia.org/wiki/Orientalism 
[11] Tavakoli-Targhi, M. (2001). Refashioning Iran: Orientalism, Occidentalism, and Historiography. New York: Palgrave Macmillan.

\section{Illustrations}

Figure 1. The Reception of Ambassadors in Damascus, Musée du Louvre, Paris, oil on canvas, 1511.

Figure 2. Walter Charles Horsley, Women and an Old Man in Harem, Oil on Canvas, 1883.

Figure 3. Henriette Brown, Visit, Harem Interior, Oil on Canvas, 1860.

Figure 4. Jacques Majorelle, L'Aouche .

Figure 5. Mohammed Racim, Persian Hunt, gouache heightened with gold, Musée National des Beaux-Arts d'Alger . 1920.

Figure 6. Adrien Dauzats, The Place du Gouvernement at Algiers, oil on canvas, Musée Condé, Cantilly 1849.

Figure 7. Théodore Chassériau, Arab Chiefs Challenging Each Other to Single Combat under the Ramparts of a City, oil on canvas, 1852.

Figure 8. Eugene Delacroix, Arab Men Smoking in front of a House.

Figure 9. Gustave Guillaumet, Weaving Women at Bou-Saâda, oil on canvas, Musée d' Orsay, Paris, 1885.

Figure 10. Jean Auguste Dominique Ingres, Turkish Bath, Musée du Louvre, Paris, oil on canvas, 1862.

Figure 11. Eugene Delacroix, Arab Fantasia, 1863.

Figure 12. H. Adrien Tanoux, the Next Commission, oil on canvas, Private Collection, 1889.

Figure 13. Eugene Delacroix ,Algerian Women in Their Apartments , Musée du Louvre, Paris, oil on canvas, 1834.

Figure 14. Houria Niati, No To Torture, National Museum of Women in the Arts, Washington, 1982. 